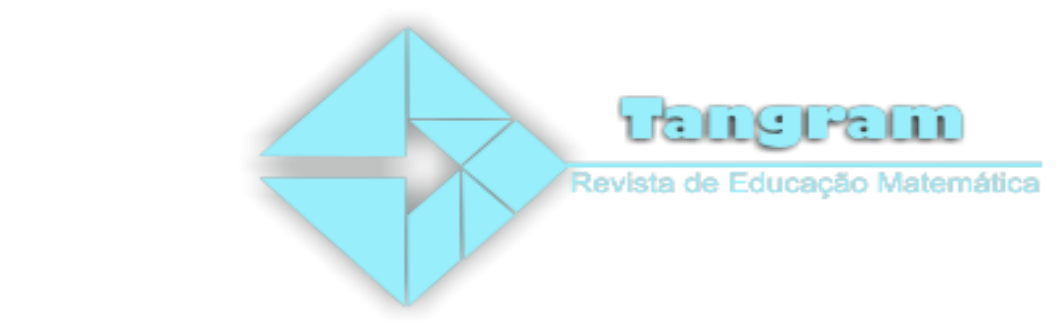

Geometric Thinking of Future Mathematics Teachers in Mozambique: a case study from Rovuma University

\title{
Pensamento Geométrico dos Futuros Professores de Matemática em Moçambique: um estudo de caso da Universidade Rovuma
}

\author{
Rosalino Subtil Chicote ${ }^{1}$ \\ Geraldo Vernijo Deixa ${ }^{2}$
}

\begin{abstract}
We developed the research with 53 students, future math teachers, from the 1st year of the Degree in Mathematics Teaching at Rovuma University. The aim was to identify the level of development of geometric thinking of future mathematics teachers. To this end, the van Hiele test was adapted. The results show that most future mathematics teachers identify classes of shapes based on properties, i.e. they are at level 2 of the van Hiele model. There is heterogeneity in the geometric thinking development of future mathematics teachers. Only 5 out of 53 respondents got all the questions in the test right. We concluded that respondents have weaknesses in mathematical knowledge inherent in quadrilaterals.
\end{abstract}

Keywords: quadrilaterals, geometric thinking, van Hiele's model

Resumo :Desenvolvemos a pesquisa com 53 estudantes, futuros professores de matemática, do $1^{\circ}$ ano do Curso de Licenciatura em Ensino de Matemática da Universidade Rovuma. O objectivo foi identificar o nível de desenvolvimento do pensamento geométrico de futuros professores de matemática. Para o efeito, foi adaptado o teste de van Hiele. Os resultados mostram que maior parte dos futuros professores de matemática identificam classes de formas com base em propriedades, isto é, situam-se no nível 2 do modelo de van Hiele. Há heterogeneidade no desenvolvimento de pensamento geométrico dos futuros professores de matemática. Apenas 5 dos 53 inquiridos acertaram todas as questões do teste. Concluímos que os inquiridos possuem fraquezas no conhecimento matemático inerente aos quadriláteros.

Palavras-chave: quadriláteros, pensamento geométrico, modelo de van Hiele

\footnotetext{
${ }^{1}$ Master in Education / Curriculum. Graduated in Teaching of Mathematics from the Pedagogical University of Mozambique. rschicote1@gmail.com

$2 \mathrm{PhD}$ in Science Teaching and Mathematical Education. Professor at Licungo University, Mozambique.gdeixa@gmail.com
}

Tangram - Revista de Educação Matemática, Dourados - MS - v.3 n.1, pp. 62-73 (2020) 


\section{Rovuma University}

\section{Introduction}

Even though successive curricular renovations were performed in Mozambique, an analysis of the current Teaching Programs allows us to recognize that the teaching of Geometry starts at $1^{\text {st }}$ grade (6-year-old students). In these Teaching Programs, the Geometry contents are distributed in spiral from the $1^{\text {st }}$ to $12^{\text {th }}$ grade (students with age around 17 years old). In this sense, an inquiry arises: could this distribution meet the particularities of teaching and learning Geometry?

Russian researchers, interested in understanding why students from $1^{\text {st }}$ grade to $7^{\text {th }}$ grade (age 6-12 years old) had low progress in Geometry when compared to other areas, conducted a research grounded in the Van Hiele Model. The research concludes that most students of the $5^{\text {th }}$ grade, over $85 \%$ of the surveyed students, had reached Level 1 of the Model. This means that about $15 \%$ of students had reached Level 2 . However, the $6^{\text {th }}$ grade required students to have reached at least Level 3 (Villiers, 2010).

The same author notes that, in South Africa, it was found that $45 \%$ of students in the $12^{\text {th }}$ grade, of a survey conducted in Kuazulo Natal, did not pass Level 2 of the Van Hiele Model. Therefore, students could not achieve good results in exams because these based on a Level 3 understanding (Villiers, 2010).

Another aspect of the situation are the teachers. In Brazil, Lorenzato (1995) states that many Mathematics teachers only apply Geometry superficially, some of them even wait until the last few weeks of classes. The cause for this phenomenon could be the poor mathematic and didactic knowledge in Geometry.

Allied to this, in Mozambique, in the current Planned Curricula for the Pedagogical University for recently created universities (UniMaputo, UniSave, UniPungue, UniLicungo and UniRovuma), the Bachelor's Degree in Mathematics Education includes a discipline called Teaching of Mathematics II (Teaching Geometry). This discipline is available in the $1^{\text {st }}$ semester of the $3^{\text {rd }}$ year, with a workload of 48 hours of contact (UP, 2014). This workload is not enough to address, in depth, didactic issues of Geometry content taught in General Secondary Education.

According to A. L. O'Toole in the article of Jones (2000), many Mathematics teachers of the General Secondary Education possess the same knowledge of Geometry that they learned as students during their own General Secondary Education classes. This indicates that the conceptions that teachers acquire in Secondary Education, as a student, are not modified during their training as teachers of Mathematics.

In Mozambique, the survey conducted by the Pedagogical University to Mathematics teachers of Secondary General Education revealed consensus among teachers about the difficulty of teaching Geometry (Diniz, 2009). As a result, from 2004 to 2007, they developed the Project UP-STTP (Support to Teacher Training Program). Yet, since it was 


\section{Rovuma University}

not a national project and without perpetuity, we believe that problems still prevail for many teachers.

When a teacher has little mathematical knowledge on a subject, they do not feel confident and will demonstrate difficulties in teaching such subject of knowledge. Naturally, this subject may not arrive in optimal conditions to students. Simply put, the consequences of the teacher's difficulties falls directly onto the students. Thus, we should understand the current situation of the level of development of the Geometric Thinking of future Mathematics teachers in a specific content, in this case, quadrilaterals.

As a result, we ask this: at what level of development of Geometric Thinking are situated future Mathematics teachers? With this research, our intention was to identify the level of development of the Geometric Thinking of future Mathematics teachers.

Given the diversity of Geometries and objectives for teaching Geometry from the XXI Century, there is a need to discuss the future of Geometry teaching in Mozambique. At first, it is important to produce evidence on our current state and then study intervention measures.

The discipline of Euclidean geometry is a specific component of the formation of the Mathematics teacher for General Secondary Education, with workload of 80 hours of contact. It is available during the second semester of the $1^{\text {st }}$ year of the Bachelor's Degree in Mathematics Education at the Pedagogical University. As we mentioned earlier, the didactic of Geometry takes place in the $1^{\text {st }}$ semester of the $3^{\text {rd }}$ year, this means that the student spends a year without contact with the Euclidean geometry content. However, Euclidean geometry contents are distributed throughout the General Secondary Education.

In a practical way, it seems to be important to prepare teachers while, at the same time, convincing them that the teaching and learning of Geometry has distinct characteristics from other areas of Mathematics. The Universities, through the initial training of Mathematics teachers, can throw seeds so that future generations will not enter, in the words of the Russian researchers, a prolonged period of geometric inactivity. It is in this context that arises the interest for further research.

\section{Theory review}

The Van Hiele Model emerged in the Netherlands in 1957 from the thesis of Dina Van Hiele-Geldof and Pierre Van Hiele (Usiskin, 1982). According to Villiers (2010), the two theses explored different aspects of Geometry. The author states that the concern of Pierre Van Hiele is to explain why students had trouble learning Geometry. On the other hand, Dina Van Hiele develops the thesis exploring how to learn Geometry.

Thus, based on the intersection of the two theses is created the Van Hiele Model. According to Kaleff et al. (1994), the model has two purposes: (i) a guide for Geometry learning, (ii) a guide to assess the level of development of the Geometric Thinking. These two areas have been explored through research that focused on different subjects: teachers, students, textbooks, curriculum materials, among others. In the context of this research, we explored the aspect (ii).

\section{Properties of the Van Hiele Model}

Tangram - Revista de Educação Matemática, Dourados - MS - v.3 n.1, pp. $62-73$ (2020) 


\section{Rovuma University}

The Van Hiele Model has a functional order of four properties to organize the five levels of development of Geometric Thinking: Fixed sequence, adjacency, distinction and separation (Usiskin, 1982).

To Usiskin (1982), the fixed sequence ensures that students cannot be at level $n$ in the Van Hiele Model without going through level $n$ - 1 . Under the same angle, Kaleff et al. (1994), argues that appropriate learning experiences are what leads a student to be located in a certain level of development of Geometric Thinking, not being possible to perform a leap to other levels without having fulfilled the requirements for the previous level.

In other words, a student will not arrive at the Level 2 of development of Geometric Thinking without having to go through the learning experiences of the Level 1 of Geometric Thinking. Therefore, fixed sequence is a property that ensures that the Geometric Thinking levels are static and hierarchically organized.

Despite the fact that the levels of Geometric Thinking development are static, each one relates to its successor by adjacency. Kaleff et al. (1994, p.6) points out that "the objects inherent to a level become objects of study for the posterior level". In other words, "what was intrinsic in the preceding level becomes extrinsic in the current level" (Usiskin apud Villiers 2010, p.401).

This means that, at each level, there is something specific to be developed and, at the next level, what had not been taken to focus becomes relevant. Therefore, the adjacency is a property that indicates a relationship between the levels of development of the Geometric Thinking according to the Van Hiele Model.

This relationship has limits because each level carries its own linguistic universe and network of relationships" (Usiskin apud Villiers 2010, p.401). The relations undergo transformations over the levels:

Thus, a relationship that is accepted as correct on one level can be adjusted in another. One example is the series of inclusion classes (e.g., a square is also a rectangle, which is also a parallelogram) however, these figures in a previous level can be considered exclusive. (Kaleff et al., 1994, p.6).

In the Van Hiele Model, this property is designated as distinction. From the above, we can understand that the level of complexity of the development of Geometric Thinking grows as the levels progresses. The distinction is a property that interprets points of divergence between levels resulting from the insertion of a new linguistic universe capable of improving the intrinsic communication level. This is a structural property.

On the other hand, the model has a similar property to its predecessor, but in functional order, that is, the linguistic universe is put into practice. For Villiers (2010), the "separation" property ensures that when subjects belonging to two different levels communicate, the language used is not the same as they relate to the same object. This has happened frequently when teaching Geometry, on the relationships between teacher, students and textbook.

\section{Levels of development of the Geometric Thinking from the Van Hiele Model}

Tangram - Revista de Educação Matemática, Dourados - MS - v.3 n.1, pp. $62-73$ (2020) 


\section{Rovuma University}

The Van Hiele Model consists of five levels. Each level has its own specificities, essentially defining traits of the students in the teaching and learning of Geometry.

To Walle apud Cunha (2016, p.25) "levels describe how we think and what types of geometric ideas, more than the amount of knowledge or information we have at each level." In other words, these levels describe the growth of the Geometric Thinking of students (Cunha, 2016, p.25). The chart below features the skills associated with each level.

Chart 1. Characterization of levels of the Van Hiele Model

\begin{tabular}{|c|l|}
\hline Level Designation & \multicolumn{1}{c|}{ General Features } \\
\hline Level 1: Recognition & $\begin{array}{l}\text { Students recognize visual forms for its overall appearance. They recognize } \\
\text { triangles, squares, parallelograms, among others, by its shape, but do not } \\
\text { identify explicitly the properties of these figures. }\end{array}$ \\
\hline Level 2: Analysis & $\begin{array}{l}\text { Students begin to analyze the properties of figures and learn the appropriate } \\
\text { technical terminology to describe them, but do not correlate figures and } \\
\text { properties. }\end{array}$ \\
\hline Level 3: Abstraction & $\begin{array}{l}\text { The students perform the logical ordering of the figures' properties through } \\
\text { short sequences of deduction to understand the correlations between figures. } \\
\text { (For example, class inclusions). }\end{array}$ \\
\hline Level 4: Deduction & $\begin{array}{l}\text { Students start developing longer sequences of statements and start to } \\
\text { understand the significance of deduction, the role of axioms, theorems and } \\
\text { proofs. }\end{array}$ \\
\hline Level 5: Rigor & Students assess deductive systems with high degree of accuracy \\
\hline
\end{tabular}

Source: adapted from VILLIERS, 2010, p. 401: Kaleff et al. (1994).

The first level of the Van Hiele Model of development of Geometric Thinking is Recognition; other researchers prefer to refer it as Visualization. At this level, the forms are taken as objects of thought.

The Geometric Thinking of students is based on visual aspects of the form (Kaleff et $a l ., 1994)$. This contributes to make them vulnerable to misidentification when the shape has an unusual orientation (VILLIERS, 2010). According to Silva (2015, p. 27).

This first level is the initial phase of the student's learning. It is when they start to identify models, shapes present in their day to day. At any time, for example, they can differentiate a square from a rectangle using their properties; they can differentiate a square from a triangle, but not through their properties, but by their physical form.

Thus, the identification, classification and description of forms is carried out based on their appearance. Thus, some skill indicators are salient, such as learning the geometric vocabulary, identifying specific shapes, reproducing the given shape (Kaleff et al, 1994).

The entry to the second level incorporates observation and experimentation leading to considering the properties of shapes. Therefore, at this level, students can envision classes and forms (Kaleff et al., 1994; Jones, 2000). In this context, the figures are classified including every property underlying them.

At Level 3, abstraction (or ordering), the definitions presented in the previous level are consolidated and take an economic character (Burger \& Shaughnessy apud Villiers, 2010). Therefore, the speech of the student involves a consistent and brief knowledge about Tangram - Revista de Educação Matemática, Dourados - MS - v.3 n.1, pp. $62-73$ (2020) 


\section{Rovuma University}

the properties, inclusion, intersection forms in classes and relationships between shapes. This indicates that:

Students are already able to differentiate figures for their properties, identifying minimum requirements that enable to identify a figure like a square and elaborate on what properties distinguish a square from a rectangle, among others. (SILVA, 2015, p.27).

Yet, "the student at this level does not understand the meaning of a deduction as a whole, or the role of axioms. Formal proofs is understood, but students do not realize how to build a proof, starting from different premises "(Kaleff et al. 1994, p.5).

The possibilities of building a demonstration as a way to a proof, gathering all products of thought acquired in the previous levels are the gymnastics of level 4 , formal deduction. The geometric reasoning is based on understanding of the functions of axioms, definitions and tests (Burger \& Shaughnessy apud Villiers, 2010). The logical serialization is directed to use certain statements to logically justify a consequence. For this reason, Kaleff et al. (1994) argues that a student at this level can develop a proof in several ways.

Level 5, rigor, products of Geometric Thinking are more demanding. Places itself as the subject of Geometric Thinking around a deductive system, which requires a high degree of accuracy. According to Kaleff et al. (1994, p.5) students at this level "are able to deepen the analysis of properties of a deductive system, such as consistency, independence and completeness of the axioms." Generally, professional mathematicians have reached this level.

The transition from a level of Geometric Thinking to another occurs gradually and does not depend on age, but the teaching method (CUNHA, 2016, JONES, 2000). It is noteworthy, in this regard, that the chronological age of the students is not a factor explaining the ease of learning Geometry. The teaching method proposed in the model presents five phases: information, directed guidance, explanation, free orientation and integration.

\section{Methodology}

Faced with the proposed problem, we have chosen to work with a qualitative approach. We prefer this approach because we will investigated the qualities of the products of Geometric Thinking of future math teachers who have space to describe them through the Van Hiele Model.

The present study included 53 students of the Bachelor's Degree in Mathematics Education at the Rovuma University. Of these, 48 males and 5 females. We worked with $1^{\text {st }}$ year students because they had just been exposed to the quadrilaterals contents through the discipline called Euclidean geometry. Therefore, the choice of respondents was intentional.

The production of data was performed from an adapted version of the Van Hiele Test. The test pattern consists of 15 questions, divided into 3 blocks. Each block corresponds to a level and has 5 questions. Below we explain the adjustments made. 


\section{Rovuma University}

In the first block (corresponds to Level 1 of the Test), the following changes were made: the number of options has been reduced from 5 to 4 ; questions relating to triangles and lines were exchanged for trapezoids and diamonds; the trapeze and rectangle were listed in relation to their usual position; some plane figures were exchanged for others.

All these changes were intended to adjust the test to the Mozambican reality. Not having undergone changes in the functional level, we consider the adapted Van Hiele Test still consistent because it maintains the essential characteristics of the original. It is worth mentioning that the adapted test was used for the production of data for a scientific monograph oriented by the first author of this article.

The Van Hiele Test was applied once with two functions: as a data production tool for research; as second written test for the discipline of Euclidean geometry. Thus, the test took place in a classroom and lasted two hours.

The material (test) was collected and placed into data analysis, starting with every respondent being encoded as $A_{1}, A_{2}, A_{3} \ldots A_{53}$. Then, we verified the data in the material in two forms: defined answers and essay answers.

We carried out a reading of every material and categorized the answers into two groups: right and wrong. This way of categorizing has been used in studies of Geometric Thinking by many researchers (Cunha, 2016; Junior and Silva, 2014). The essay answers were analyzed as previously mentioned and by an understanding of the manifest content (Bardin, 2011).

Another moment of the analysis was the application of the categories a priori (Level 1 - recognition, Level 2 - analysis, Level 3 - ordering / informal deduction) defined by the Van Hiele Model. We framed the students' answers within these categories. It is worth mentioning that we only worked with three levels of the model because the original test also had this characteristic.

When deciding about levels (1,2 and 3) we defined the following rule: the student who misses two questions of a level belongs to the previous level. To belong to Level 3, we consider those who have missed just one of the questions of the level in question. Based on these rules came another category, a posterior. This category concerns the $\mathrm{A}_{53}$ who missed two questions related to Level 1, and was classified without any level of experience. Therefore, this fact reduced the distribution of students down to 52 research subjects in three levels.

\section{Results and discussion}

The first Block, which corresponds to the Level 1 of the adapted van Hiele test, has five questions (1, 2, 3, 4 and 5). Each question seeks to verify the ability to identify quadrilaterals. We present below as an example, the first question of the test.

Question N 1. Properly identify the trapeze

Tangram - Revista de Educação Matemática, Dourados - MS - v.3 n.1, pp. $62-73$ (2020) 
Geometric Thinking of Future Mathematics Teachers in Mozambique: a case study from

Rovuma University

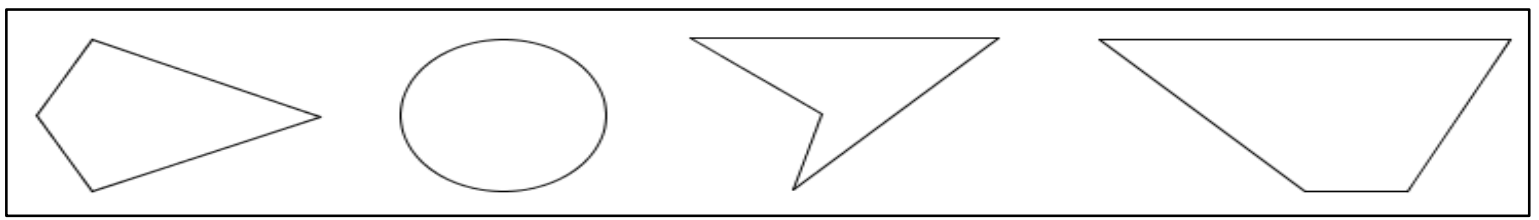

Source: Adapted Van Hiele Test, 2019.

In this question, future Mathematics teachers should mark an X on the corresponding figure a proper trapeze. According to the data, 11 of the Level 1 students have answered correctly, and marked the last form of the right side.

Likewise, even those who only classified at Level 1, have also correctly answered questions 3 and 5 of block 1 . In a global context, Chart 1 shows that 11 of the 53 surveyed students were found to not possess skills to reach the second level of the model. In the referred block, question 4 was the one that recorded more incorrect answers, a total of 3 errors. Chart 1 shows the results of block 1 (all five questions).

Chart 2: Participants who missed at least two Level 2 questions

\begin{tabular}{|l|c|c|}
\hline Level 1: Recognition & Participants & fi \\
\hline Can identify forms & $\mathrm{A}_{5} \mathrm{~A}_{9} \mathrm{~A}_{11} \mathrm{~A}_{13} \mathrm{~A}_{25} \mathrm{~A}_{29} \mathrm{~A}_{31} \mathrm{~A}_{34} \mathrm{~A}_{41} \mathrm{~A}_{51} \mathrm{~A}_{52}$ & 11 \\
\hline
\end{tabular}

Source: survey data, in 2019.

At Level 1, 8 out of 11 students correctly answered every question (A ${ }_{9} \mathrm{~A}_{11} \mathrm{~A}_{28} \mathrm{~A}_{30}$ $\mathrm{A}_{33} \mathrm{~A}_{40} \mathrm{~A}_{50} \mathrm{~A}_{51}$ ). In the research of Cunha (2016), it was found that one of the quadrilaterals that creates problems in their identification is the proper trapeze. Junior and Silva (2014), upon applying a van Hiele test to future Mathematics teachers, found that they were more likely to correctly identify the square. However, the primacy of the visual aspects of the form leads to errors when the quadrilateral presents differently from the usual orientation (VILLIERS, 2010).

In Block 2, which corresponds to Level 2 of the van Hiele test, consists of 5 questions $(6,7,8,9$ and 10). In this block, we highlight question number 7 , which 7 of the 22 surveyed students that classified at this level, made mistakes in their answers.

Question No.7. Provide three characteristics of parallelograms:

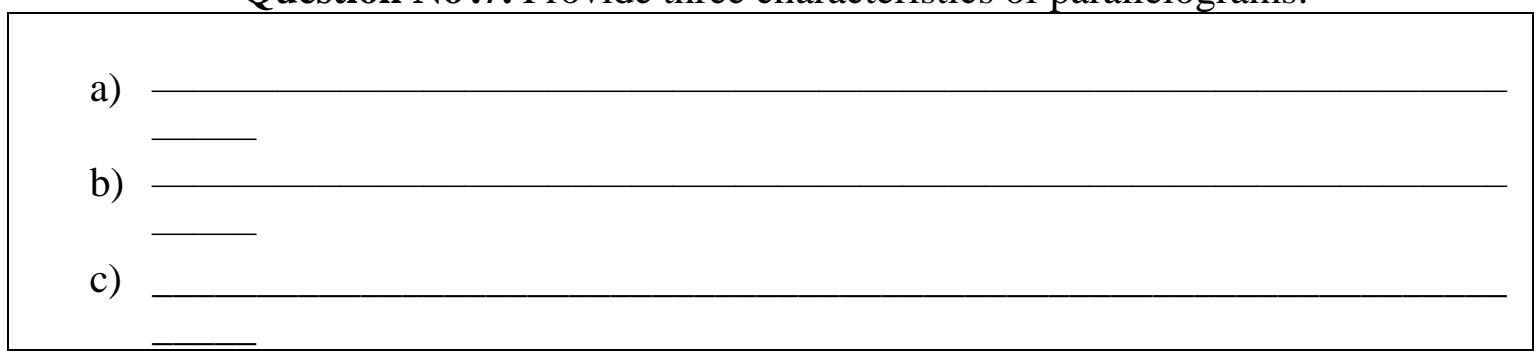

Source: Adapted Van Hiele Test, 2019.

The surveyed students $\mathrm{A}_{4}, \mathrm{~A}_{17}, \mathrm{~A}_{37}, \mathrm{~A}_{38} \mathrm{~A}_{42}, \mathrm{~A}_{45}, \mathrm{~A}_{52}$ incorrectly mentioned properties of parallelograms, in a sense: has right angles, has equal sides, has four right angles, the sum of the interior angles results in 180 degrees, has equally measured diagonals. This property is correct to the extent that is associated with a particular class of parallelograms. It is worth

Tangram - Revista de Educação Matemática, Dourados - MS - v.3 n.1, pp. $62-73$ (2020) 


\section{Rovuma University}

mentioning that a similar question to that, referring to the property of squares, was part of the Junior and Silva's research (2014) where 10 of the 17 future Bachelor's Degree in Mathematics teachers answered incorrectly.

It becomes evident that identifying a class of forms from their properties is an activity that requires some level of Geometric Thinking more demanding than performing classification of forms based on the visual aspect.

In the survey, although these respondents belong to the second level, we understand their difficulties in determining the underlying property to all parallelograms. This difficulty has also been reported in the research of Cunha (2016). The author states that the reason for this may be the lack of knowledge about such property. This result is based on Silva (2015), stating that the quadrilaterals are known to the students based on their shapes, not their properties.

Chart 3. Participants who missed at least two Level 3 questions

\begin{tabular}{|l|l|c|}
\hline Level 2: Analysis & \multicolumn{1}{|c|}{ Participants } & fi \\
\hline $\begin{array}{l}\text { Can identify classes of forms based } \\
\text { on properties }\end{array}$ & $\begin{array}{l}\mathrm{A}_{1} \mathrm{~A}_{2} \mathrm{~A}_{4} \mathrm{~A}_{7} \mathrm{~A}_{16} \mathrm{~A}_{17} \mathrm{~A}_{18} \mathrm{~A}_{22} \mathrm{~A}_{25} \mathrm{~A}_{26} \mathrm{~A}_{27} \mathrm{~A}_{32} \\
\mathrm{~A}_{37} \mathrm{~A}_{38} \mathrm{~A}_{41} \mathrm{~A}_{42} \mathrm{~A}_{43} \mathrm{~A}_{45} \mathrm{~A}_{47} \mathrm{~A}_{48} \mathrm{~A}_{49} \mathrm{~A}_{52}\end{array}$ & 22 \\
\hline
\end{tabular}

Source: survey data, in 2019.

In the questions relating to this block, half of the respondents correctly answered all five questions ( $\mathrm{A}_{1} \mathrm{~A}_{7} \mathrm{~A}_{18} \mathrm{~A}_{25} \mathrm{~A}_{26} \mathrm{~A}_{27} \mathrm{~A}_{32} \mathrm{~A}_{41} \mathrm{~A}_{43} \mathrm{~A}_{47} \mathrm{~A}_{49}$ ). In overall, 22 of 53 respondents revealed to possess skills corresponding to the second level of Geometric Thinking in the Van Hiele Model. This means that they understand the properties of the forms and can organize them into classes (Cunha, 2016). Continuing, we present the participants who incorrectly answered only one question in the chart below.

Chart 4. Participants who miss only one question of Level 3

\begin{tabular}{|c|c|c|}
\hline Level 3: ordering & Participants & fi \\
\hline $\begin{array}{l}\text { Can establish relationships } \\
\text { between properties of forms }\end{array}$ & $\begin{array}{l}A_{3} A_{6} A_{8} A_{10} A_{13} A_{14} A_{15} A_{19} A_{20} A_{21} \\
A_{23} A_{29} A_{31} A_{34} A_{35} A_{36} A_{39} A_{44} A_{46}\end{array}$ & 19 \\
\hline
\end{tabular}

Source: survey data, in 2019.

The surveyed students $\left(A_{10}, A_{13}, A_{34}, A_{35}, A_{36}, A_{39}\right)$ answered correctly every question in Block 3 . The other students missed only one question, mainly question 14. In summary, 19 of 53 surveyed students understand the correlation between figures. Difficulties in arriving at Level 3 are also evident in other research (Junior and Silva, 2014; Cunha, 2016).

Accordingly, 1 out of 53 students could not reach Level 1, 19 of 53 are located at Level 3, 22 of 53 are at the Level 2, and 11 of 53 are at Level 1. Therefore, our research shows that the deficiencies, in the mathematical knowledge of quadrilaterals, of the future Mathematics teachers, should be addressed before entering the University, given that these difficulties were not addressed, what to do? Below we summarize the results of this research. 
Geometric Thinking of Future Mathematics Teachers in Mozambique: a case study from

Rovuma University

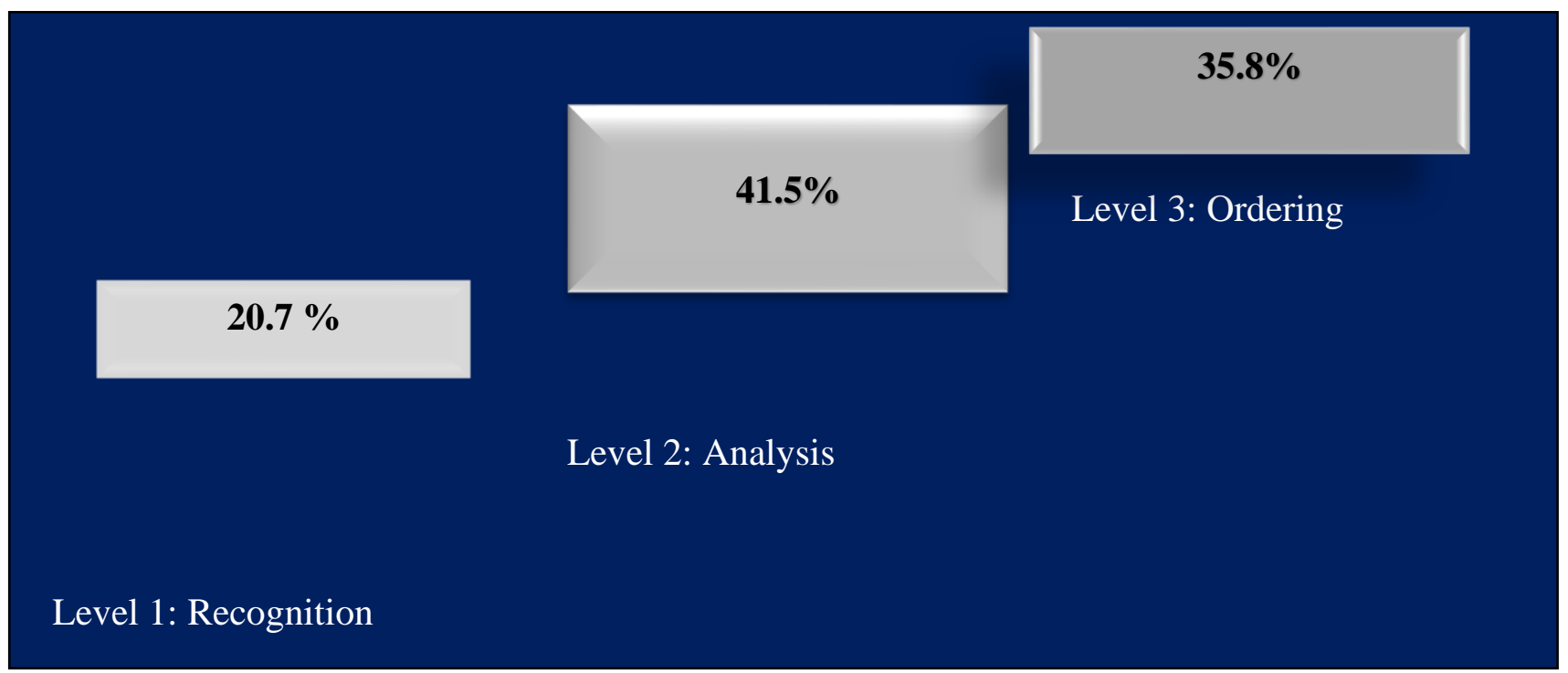

The starting point of the research was as follows: at what level of development of Geometric Thinking are situated future Mathematics teachers? With this research, we intend to identify the level of development of the Geometric Thinking of future Mathematics teachers.

Data analysis revealed that 35.8\% (19 of 53) are located at the Level 3, 41.5\% (22 of 53) at Level 2 and 20.7\% (11 of 53) at Level 1, 18\% (1 of 53) did not reach even the Level 1 of the Van Hiele Model. Only 9\% (5 of 53) of students answered correctly all 15 questions of the van Hiele test. It should be noted that these students are part of the 19 located on Level 3.

Given that the research involved college students who had contact with Euclidean geometry since primary school, it was assumed that most were at Level 3 of the Van Hiele Model, however, the results indicate the opposite, highlighting the need for the institutions forming teachers to rethink the teacher training curriculum, specifically in the Geometry area.

We corroborate with this research the notion that Geometry is one of the most problematic branches of Mathematics. The lack of mathematical knowledge will follow its course to the stage where these subjects assume classes as teachers. With that said, the universities need to conduct follow-ups with their graduates in order to suppress a few pedagogical issues.

\section{Bibliography}

Cunha, Anne de Souza.(2016) The construction of Geometric Thinking: Visualization and analysis of quadrilaterals. [A construção do pensamento geométrico: visualização e análise dos quadriláteros]. Final paper presented to the coordination of the Bachelor's degree in Tangram - Revista de Educação Matemática, Dourados - MS - v.3 n.1, pp. $62-73$ (2020) 


\section{Rovuma University}

Mathematics Education as partial requirement for the Bachelor's title. Federal University of Paraiba. $2016 . \quad$ Available in https://repositorio.ufpb.br/jspui/bitstream/123456789/3361/1/ASC12072016.pdf

Captured on November 15, 2019.

Silva, Cleidison, Cândido da. (2015) The Levels of Geometric Thinking in the Van Hiele Model: a case study involving quadrilaterals. [Os Níveis do Pensamento Geométrico no modelo Van Hiele: um estudo de caso envolvendo quadriláteros]. Final paper presented to the coordination of the Bachelor's degree in Mathematics Education as partial requirement for the Bachelor's title. Federal University of Paraiba. Available in https://repositorio.ufpb.br/jspui/bitstream/123456789/3762/1/CCS13042015.pdf . Captured at 12 October 2019.

Villiers, Michael de. (2010) Some reflections on the Van Hiele Theory. EDUC. MATHEMATICS RES., São Paulo, v.12, n.3, pp. 400-431. Translation by Celina AAP Abar - abarcaap@pucsp.br for publication in the journal Mathematics Education Research (Revista Educação Matemática Pesquisa), with permission of the author from the original version presented in IV Mathematics Teachers Congress the Croatian Mathematical Society, Zagreb, June 30 to July 2, 2010.

Diniz, Paul. (2009) Teaching Geometry in $9^{\text {th }}$ grade in Mozambique: Three teachers tackling the curriculum. [O ensino da Geometria na 9. ${ }^{a}$ classe em Moçambique: três professores tacteando o currículo]. Master's thesis, Education (Teaching of Mathematics), University of Lisbon, Faculty of Sciences. Available in http://hdl.handle.net/10451/4942 Captured on October 07, 2019.

Jones, Keith. (2000), Critical Issues in the Design of the Geometry Curriculum. In: Bill Barton (Ed) Readings in Mathematics Education. Auckland, New Zealand: University of Auckland. pp. 75-90.

Junior, José Roberto Costa: SILVA, João Batista Rodrigues da. (2014) Geometry from the perspective of the Van Hiele Theory: a development level analysis of the Geometric Thinking of students of a Bachelor's Degree in Mathematics Education. [A Geometria pela ótica da Teoria de van Hiele: uma análise do nível de desenvolvimento do pensamento geométrico de alunos de um curso de Licenciatura em Matemática.] Developing Mathematical Thinking in Miscellaneous Educational Spaces 27 to 29 November UEPB Campina Grande, Paraíba.

Kaleff, Ana, Maria, et al. (1994) The Development of Geometric Thinking - Model Van Hiele. [Desenvolvimento do Pensamento Geométrico - O Modelo de Van Hiele]. Bolema, Rio Claro - SP, v. 9, no. 10.

Lorenzato, S. (1995) Why not teach Geometry? [Por que não ensinar Geometria? A educação matemática em revista]. Mathematics Education Magazine. GEOMETRY. Blumenau, Number 04, p.03-13. Special Edition

UP (2014) Curricular Plan of the Bachelor's Degree in Mathematics Education. [Plano Curricular do Curso de Licenciatura em Ensino de Matemática]. Mozambique, Maputo City.

Tangram - Revista de Educação Matemática, Dourados - MS - v.3 n.1, pp. $62-73$ (2020) 
Geometric Thinking of Future Mathematics Teachers in Mozambique: a case study from

\section{Rovuma University}

Usiskin, Zalman. (1982) Van Hiele levels and Achievement in Secondary School Geometry. Final report of the CDASSG Project. Chicago: Univ. of Chicago. Available in https://files.eric.ed.gov/fulltext/ED220288.pdf Captured on 01 July 2019.

Recebido: $13 / 02 / 2020$

Aprovado:28/03/2020

Tangram - Revista de Educação Matemática, Dourados - MS - v.3 n.1, pp. $62-73$ (2020) 